\title{
EFEKTIVITAS IKLAN TELEVISI UNILEVER INDONESIA MENGENAI COVID-19
}

\author{
Ayu Priana \\ AyuPriana1410618026@mhs.unj.ac.id \\ Program Studi IlmuKomunikasi, Universitas Negeri Jakarta, \\ Jl. RawamangunMuka RT.11/RW.14, Rawamangun, PuloGadung, Kota \\ Jakarta Timur, DKI Jakarta, 13220, Indonesia.
}

Submitted: 29 Juni 2020| Accepted: 24 September 2020 | Published: 30

Desember 2020

Website: https://e-journal.umc.ac.id/index.php/jike/index

\begin{abstract}
Advertising is one of the important things for advertisers to provide information to the audience. Covid-19 is a national disaster that is happening in Indonesia. This study wanted to find out the effectiveness of television commercials about Covid-19 from Unilever Indonesia entitled "K-U-N-C-I Menangkal Virus Corona". This research uses a descriptive quantitative approach with survey methods. The results of this study indicate that all dimensions used in the questionnaire have an average value of above 2.5 , which means that a television advertisement about Covid-19 from Unilever Indonesia entitled "K-U-N-C-I Menangkal Virus Corona" has been effective.

Keywords: effectiveness, television advertising, covid-19.
\end{abstract}

\begin{abstract}
Abstrak
Iklan merupakan salah satu hal yang penting bagi pengiklan untuk memberikan informasi kepada khalayak. Covid-19 merupakan bencana nasional yang sedang melanda Indonesia. Penelitian ini ingin mencaritahu efektivitas dari iklan televise mengenai Covid-19 dari Unilever Indonesia yang berjudul "K-U-N-C-I Menangkal Virus Corona". Penelitian ini menggunakan pendekatan kuantitatif deskriptif dengan metode survei. Hasil penelitian ini menunjukkan bahwa seluruh dimensi yang digunakan dalam kuesioner memiliki nilai rata-rata di atas 2,5, yang berarti bahwa iklan televise mengenai Covid-19 dari Unilever Indonesia yang berjudul "K-U-N-C-I Menangkal Virus Corona" sudah efektif.
\end{abstract}

Kata Kunci:efektivitas, iklantelevisi, covid-19.

\section{A. PENDAHULUAN}

Iklan menjadi salah satu media yang digunakan oleh pengiklan untuk menyampaikan pesan kepada audien satau khalayaknya. Pesan yang dimaksud dapat berupa memperkenalkan produk baru, menarik perhatian konsumen, memberikan edukasi atau tata cara penggunaan suatu produk, mempertahankan loyalitas pelanggan, hingga hanya untuk sekedar menyampaikan suatu informasi kepada khalayak.Terdapat beberapa media komunikasi yang digunakan oleh pengiklan seperti televisi, radio, surat kabar, majalah, media sosial, hingga iklan luar ruangan seperti baliho atau billboard.

Salah satu media massa yang masih banyak digunakan untuk memasang iklan adalah televisi. Hal tersebut dikarenakan televise dianggap memiliki fungsi yang lebih efektif dalam 
menyampaikan pesan dan memengaruhi masyarakat. Kelebihan lain dari televise adalah memiliki sifat audio visual yang berisi kombinasi warna-warna, gerakan dan suara, sehingga membuat iklan yang ada di televise lebih hidup dan nyata serta menjadikan televise memiliki pengaruh yang sangat kuat dalam mempersuasi orang lain (Hastuti, 2013). Oleh karenanya, banyak pengiklan masih menggunakan televise sebagai media pemasangan iklan hingga saat ini. Televisi sebagai media massa digunakan untuk menyebarkan informasi kepada khalayak luas secara serentak. Penyebaran informasi melalui televise dinilai lebih efisien karena dapat menjangkau masyarakat yang luas sekaligus pada waktu yang bersamaan. Pemasangan iklan pada televisi juga dimaksudkan untuk menyebarkan informasi dari pengiklan kepada masyarakat. Menurut Biagi (2010), mengiklankan juga dimaksudkan untuk membujuk (Biagi, 2010).

Durasi menonton televisi di Indonesia juga masih tergolong tinggi. Menurut studi Nielsen pada tahun 2018, rata-rata durasi menonton televisi oleh pemirsa di Indonesia mencapai 4 jam 53 menit setiap hari. Angka tersebut lebih tinggi disbanding nilai rata-rata media lainnya, seperti rata-rata mengakses internet sebanyak 3 jam 14 menit, mendengarkan radio sebanyak 2 jam 11 menit, membaca Koran sebanyak 31 menit, dan membaca majalah sebanyak 24 menit (Fajar, 2019).

Berkaitan dengan data di atas, dapat diketahui bahwa televise masih menjadi media yang digemari penonton, dengan rata-rata durasi menonton televise lebih banyak dibandingkan dengan media lain. Oleh karenanya, masih banyak pengiklan yang menempatkan iklan mereka di televisi. Iklan digunakan sebagai media untuk menyampaikan pesan kepada audiens luas mengenai berbagai hal. Mulai dari perkenalan produk baru, iklan yang digunakan untuk melakukan suatu gerakan sosial, hingga iklan yang mengedukasi masyarakat. Salah satu iklan yang berfungsi untuk menyampaikan informasi edukasi untuk masyarakat adalah iklan yang dibuat oleh Unilever Indonesia dengan judul "K-U-N-C-I Menangkal Virus Corona”. Seperti yang kita ketahui, salah satu masalah sosial yang sedang dihadapi oleh hamper seluruh masyarakat di dunia saat ini adalah virus Covid-19.Virus tersebut diidentifikasi mirip dengan SARS coronavirus dan MERS coronavirus pertama kali muncul di Wuhan, China, pada Desember 2019 dan per tanggal 8 Februari 2020 angka kasus terkonfirmasi sebanyak 33.784 kasus dengan total 811 kematian di Tiongkok (Liu, Gayle, Wilder-Smith, \& Rocklöv, 2020).Covid-19 pun menyebar ke hamper seluruh negara di belahan dunia, termasuk Indonesia. Virus yang tergolong baru dan langsung menjadi bencana nasional di Indonesia ini pun menjadi sesuatu yang menghantui dan menimbulkan 
kebingungan di antara masyarakat. Oleh karenanya, banyak bermunculan informasi mengenai Covid-19 di berbagai media, termasuk iklan televisi yang dibuat oleh Unilever Indonesia dengan judul "K-U-N-C-I Menangkal Virus Corona". Berdasarkan uraian tersebut, penulis merasa tertarik melakukan penelitian tentang efektivitas iklan televise mengenai Covid-19 untuk mengetahui seberapa efektif iklan tersebut.

Penelitian terkait pernah dilakukan oleh Sri Hastuti dengan judul "Efektivitas Iklan Layanan Masyarakat di Televisi” yang terbit di Jurnal Ilmu Komunikasi, Vol.2 No.2 pada September 2013. Hasil analisis pada penelitian tersebut dapat diambil kesimpulan bahwa uji secara bersama factor daya tarik, kualitas pesan, dan frekuensi penayangan iklan memberikan hubungan yang signifikan dan positif terhada pefektivitas iklan layanan masyarakat Gas LPG 3 kilogram di televise (Hastuti, 2013).

Kemudian penelitian terkait juga dilakukanoleh Thirsa Octaviani dengan judul "Efektifitas Iklan Televisi Bukalapak edisi "Gunakan Jarimu dan Jadilah Pahlawan di Bukalapak" pada Masyarakat Surabaya" yang terbit di Jurnal E-Komunikasi Vol.4 No.1 tahun 2016. Hasil penelitian tersebut menunjukkan bahwa iklan televise Bukalapak edisi “Gunakan Jarimu dan Jadilah Pahlawan di Bukalapak" tergolong efektif dan berhasil memenuhi tujuan yang ingin dicapai oleh pihak Bukalapak, yakni tingkat kesadaran mencapai sebesar 85 persen (Octavianti, 2016).

Selanjutnya penelitian sebelumnya yang terkait, juga dilakukan oleh Lisa Gunawan dengan judul "Efektifitas Iklan Televisi Suzuki Karimun Wagon R di Masyarakat Surabaya” yang terbit di Jurnal E-Komunikasi Vol.2 No.3 Tahun 2014. Hasil dari penelitian tersebut, menyimpulkan bahwa iklan televisi Suzuki Karimun Wagon R sudah efektif (Gunawan, 2014).

Berhubungan dengan beberapa penelitian terkait tersebut, dapat diketahui beberapa persamaan dan perbedaan dengan penelitian ini. Persamaannya adalah memiliki variabel yang sama, yakni efektifitas iklan. Sedangkan perbedaannya terdapat pada objek yang diteliti, yakni di mana pada penelitian "Efektivitas Iklan Layanan Masyarakat di Televisi" yang dilakukan oleh Sri Hastuti, iklan televisi yang diteliti adalah iklan layanan masyarakat Gas LPG 3 Kilogram. Kemudian pada iklan "Efektifitas Iklan Televisi Bukalapak edisi “Gunakan Jarimu dan Jadilah Pahlawan di Bukalapak” pada Masyarakat Surabaya" yang dilakukan oleh Thirsa Octaviani tersebut meneliti iklan televise Bukalapak, dan pada penelitian yang berjudul "Efektifitas Iklan Televisi Suzuki Karimun Wagon R di Masyarakat Surabaya" yang diteliti oleh Lisa Gunawan, meneliti iklan televisi Suzuki Karimun Wagon 
R. Sedangkan pada penelitian ini, iklan yang diteliti adalah iklan televise mengenai Covid-19 dari Unilever Indonesia yang berjudul “K-U-N-C-I Menangkal Virus Corona”.

Berdasarkan penjelasan di atas, dapat diketahui bahwa rumusan masalah dari penelitian ini adalah "bagaimana efektivitas iklan televisi Unilever Indonesia mengenai Covid-19?". Adapun tujuan yang ingin dicapai oleh peneliti dalam penelitian ini, antara lain sebagai berikut:

1. Untuk mengetahui efektivitas iklan televise Unilever Indonesia mengenai Covid19.

2. Untuk menemukan hasil penelitian yang nantinya dapat memberikan sumbangsih informasi yang dapat digunakan sebagai bahan evaluasi tentang efektivitas iklan televise mengenai Covid-19.

3. Untuk menemukan hasil penelitian sebagai pengembangan ilmu pengetahuan.

Berdasarkan latarbelakang yang telah diuraikan di atas, peneliti merasa tertarik untuk meneliti dan mengetahui seberapa efektif iklan televise Unilever Indonesia mengenai Covid19. Penelitian ini dilakukan selama bulan April-Mei 2020 di Jakarta, Indonesia.

\section{B. TINJAUAN PUSTAKA}

\section{Efektivitas Iklan}

Menurut Effendy, efektifitas iklan merupakan sebuah kondisi sejauh mana efek dari pesan iklan yang diberikan mampu untuk menarik perhatian, dipahami, dimengerti, dapat membangkitkan emosi sasarannya, dan mampu untuk menggerakan sasarannya member tanggapan sesuai dengan apa yang dikehendaki (Gunawan, 2014).Penelitian ini menggunakan Direct Rating Model untuk mengukur tingkat efektivitas dari iklan. Menurut Durianto, Direct Rating Model dipakai untuk memberikan evaluasi mengenai kekuatan sebuah iklan yang berhubungan dengan kemampuan iklan tersebut dalam mendapat perhatian, kemudahan iklan untuk dibaca, kemudahan untuk dipahami, kemampuan iklan dalam memengaruhi perasaan, dan kemampuan iklan dalam mempengaruhi sikap atau perilaku penontonnya (Ardhi \& Sastika, 2018).

Selanjutnya, menurut Durianto dalam Shauma \& A (2015), penggunaan Direct Rating Model ditunjukkan untuk mengetahui tingkat attention, readthrougness, cognitive, dan behaviour. Direct Rating Model memiliki lima dimensi, yakni sebagai berikut:

a. Perhatian (attention) 
Dimensi perhatian (attention) mengukur mengenai seberapa baik iklan tersebut dalam menarik perhatian penonton. Dimensi pertahian memiliki dua indikator, yakni determinan pribadi dan determinan stimulus.

b. Pemahaman (readthrougness)

Dimensi pemahaman (readthrougness) mengukur mengenai seberapa baik iklan tersebut dapat dimengerti oleh penonton. Dimensi pemahaman memiliki beberapa indikator, yakni kategori stimulus, elaborasi stimulus, determinan pribadi, dan determinan stimulus.

c. Respon kognitif (cognitive)

Dimensi kognitif (cognitive) mengukur mengenai seberapa jelas pesan dari iklan dan bagaimana manfaat kontrolnya. Dimensi kognitif memiliki beberapa subindikator, yakni kesan terhadap pesan atau produk, kesan terhadap sumber pesan, dan kesan terhadap daya tarik iklan.

d. Respon Afektif (affection)

Dimensi afektif (affection) mengukur mengenai seberapa efektif sebuah daya tarik dari iklan terhadap penonton. Dimensi afektif memiliki beberapa subindikator, seperti Hasrat, preferensi iklan, dan pendirian.

e. Sikap terhadap iklan (behaviour)

Dimensi sikap terhadap iklan (behaviour), mengukur mengenai seberapa baik iklan tersebut dapat memberikan arah terhadap tindakan penonton. Sub indicator dari dimensi sikap terhadap iklan adalah diukur berdasarkan iklan tersebut disukai atau tidak oleh penonton. (Shauma \& A, 2015)

\section{Iklan Televisi}

Iklan televisi merupakan suatu film persuasive yang cenderung sangat pendek, disiarkan kepada khalayak pada menit-menit di sela program, atau ketika program dengan sengaja diberhentikan untuk menyiarkan iklan (Gunawan, 2014). Hampir semua media dapat dipakai untuk beriklan, namun salah satu iklan yang paling efektif adalah iklan televisi yang dianggap sebagai format iklan massal yang paling efektif (Veerkumar \& Jaiswal, 2015).

\section{METODE PENELITIAN}

Pendekatan yang digunakan dalam penelitian ini adalah kuantitatif deskriptif dengan 
metode survei. Penelitian deskriptif dipakai dalam memberikan suatu penjelasan rinci mengenai suatu fenomena dan biasanya hasilnya merupakan tipologi atau pola mengenai fenomena yang dibahas (Priyono, 2016). Teknik pengumpulan data penelitian ini dengan menyebarkan kuesioner kepada responden. Data primer didapat dari hasil survei yang disebar dan data sekunder dikumpulkan dari berbagai buku dan penelitian terdahulu yang berhubungan degan penelitian ini.

Populasi penelitian ini merupakan mahasiswa program studi Ilmu Komunikasi Universitas Negeri Jakarta angatan 2018 sebanyak 37 orang. Penelitian ini menggunakan analisis deskriptif, yakni dengan cara menjelaskan hasil data yang ditemukan melalui ukuran statistic seperti mean, median, modus, dan standar deviasi (Sekarwulan, Novita, Jamil, \& Safitri, 2020). Penelitian ini menggunakan teknik penarikan sampel simple random sampling atau sampel acak sederhana. Teknik acak sederhana dipakai jika melakukan penelitian dengan populasi yang homogen dan dengan jumlah populasi yang tidak terlalu banyak (Priyono, 2016). Jumlah sampel penelitian ini ditentukan dengan rumus Slovin. Adapun rumus Slovin sebagai berikut (Priyono, 2016):

$\mathrm{n} \quad=$ jumlahsampel

$$
n=\frac{N}{1+N e^{2}}
$$

$\mathrm{N} \quad=$ jumlahpopulasi

$\mathrm{e} \quad=$ nilaikritis yang diinginkan

Adapun dapat diketahui jumlah sampel penelitian ini adalah sebanyak 34 responden dengan penjabaran perhitungan sebagai berikut:

$$
\begin{aligned}
& n=\frac{N}{1+N e^{2}} \\
& \boldsymbol{n}=\frac{37}{1+37(0.05)^{2}} \\
& =33,86 \text { dibulatkan menjadi } 34 \text {. }
\end{aligned}
$$

$\mathrm{n} \quad=33,86$

$\mathrm{N} \quad=37$

$\mathrm{e} \quad=5 \%(0,05)$

Berdasarakan penjelasan di atas, dapat diketahui jumlah responden penelitian ini sebanyak 34 orang. Variabel penelitian ini adalah efektivitas iklan. Seperti yang sudah dituliskan pada bab sebelumnya, variable efektivitas iklan memiliki lima dimensi yakni dimensi perhatian, pemahaman, respon kognitif, respon afektif, dan sikap. Dimensi tersebut memiliki beberapa indikator yang dituliskan pada table operasional konsep seperti berikut.

Tabel 1. Operasional Konsep

\begin{tabular}{|c|l|l|l|c|}
\hline Konsep & Variabel & \multicolumn{1}{c|}{ Dimensi } & \multicolumn{1}{c|}{ Indikator } & Skala \\
\hline \multirow{2}{*}{} & & a. Perhatian & $\begin{array}{l}\text { a. Determinan pribadi } \\
\text { b. Determinan stimulus }\end{array}$ & \\
\cline { 3 - 4 } & & &
\end{tabular}




\begin{tabular}{|c|c|c|c|c|}
\hline \multirow{4}{*}{ Periklanan } & \multirow{4}{*}{ EfektivitasIklan } & b. Pemahaman & $\begin{array}{l}\text { a. Kategori stimulus } \\
\text { b. Elaborasi stumulus } \\
\text { c. Determinan pribadi } \\
\text { d.Determinan stimulus }\end{array}$ & \multirow{4}{*}{ Likert } \\
\hline & & c.Responkognitif & $\begin{array}{l}\text { a. Kesan terhadap } \\
\text { produk/pesan } \\
\text { b. Kesan terhadap } \\
\text { sumber pesan } \\
\text { c. Kesan terhadap daya } \\
\text { tarik iklan }\end{array}$ & \\
\hline & & d. ResponAfektif & $\begin{array}{l}\text { a. Hasrat } \\
\text { b. Peferensi } \\
\text { c. Pendirian }\end{array}$ & \\
\hline & & e. Sikap & a. Iklan disukai/tidak & \\
\hline
\end{tabular}

\section{HASIL DAN PEMBAHASAN}

Peneliti telah melakukan proses pengambilan data melalui kuesioner yang telah disebar kepada sejumlah responden. Proses pengambilan data dilakukan pada bulan Mei 2020. Kuesioner dibuat berdasarkan dimensi dan indikator yang ada pada table operasional konsep di atas. Berikut merupakan hasil jawaban dari keseluruhan responden pada setiap pernyataan dari kusioner yang telah disebar.

Tabel 2. Kebutuhan Informasi Mengenai Covid-19

\begin{tabular}{|c|c|c|c|}
\hline Pernyataan & Frekuensi & Persentasi & $\begin{array}{c}\text { Rata- } \\
\text { rata }\end{array}$ \\
\hline 4 = Sangat Setuju & 19 & $55,9 \%$ & \multirow{5}{*}{3.55} \\
\hline $3=$ Setuju & 15 & $44,1 \%$ & \\
\hline $2=$ Tidak Setuju & 0 & $0 \%$ & \\
\hline 1 = Sangat Tidak Setuju & 0 & $0 \%$ & \\
\hline Total & 34 & $100 \%$ & \\
\hline
\end{tabular}

Berdasarkan tabel 2 tentang kebutuhan akan informasi mengenai Covid-19, dapat diketahui mayoritas responden menjawab sangat setuju bahwa mereka membutuhkan informasi mengenai Covid-19. Sebanyak 19 dari total 34 responden menjawab sangat setuju dengan persentasi sebesar 55,9\%. Selanjutnya sebanyak 15 responden $(44,1 \%)$ menjawab setuju bahwa mereka membutuhkan informasi mengenai Covid-19. Berkaitan dengan iklan televise mengenai Covid-19 dari Unilever Indonesia yang berjudul "K-U-NC-I Menangkal Virus Corona", iklan tersebut menghadirkan informasi mengenai Covid19, yang mana dibutuhkan oleh para responden. Rata-rata dari pernyataan ini sebesar 3.55 yang berarti bahwa iklan tersebut efektif untuk memberikan informasi mengenai Covid-19. 
Tabel 3. Pesan Iklan Tidak Bertentangan dengan Keyakinan Responden

\begin{tabular}{|c|c|c|c|}
\hline Pernyataan & Frekuensi & Persentasi & $\begin{array}{c}\text { Rata- } \\
\text { rata }\end{array}$ \\
\hline 4 = SangatSetuju & 15 & $44,1 \%$ & \multirow{5}{*}{3.41} \\
\hline $3=$ Setuju & 18 & $52,9 \%$ & \\
\hline $2=$ TidakSetuju & 1 & $2,9 \%$ & \\
\hline 1 = SangatTidakSetuju & 0 & $0 \%$ & \\
\hline Total & 34 & $100 \%$ & \\
\hline
\end{tabular}

Berdasarkan tabel 3 tentang pesan iklan tidak bertentangan dengan keyakinan responden di atas, dapat diketahui bahwa paling banyak responden menjawab setuju bahwa pesan pada iklan televise mengenai Covid-19 dari Unilever Indonesia yang berjudul "K-U-N-C-I Menangkal Virus Corona" tidak bertentangan dengan keyakinan responden. Sebanyak 15 responden $(44,1 \%)$ menjawab sangat setuju, 18 responden $(52,9 \%)$ menjawab setuju, 1 responden (2,9\%) menjawab tidak setuju, dan tidak ada yang menjawab sangat tidak setuju. Berdasarkan data tersebut dapat diketahui bahwa mayoritas responden sepakat bahwa pesan dalam iklan televise mengenai Covid-19 dari Unilever Indonesia yang berjudul "K-U-N-C-I Menangkal Virus Corona", tidak bertentangan dengan keyakinan responden.

Tabel 4. Gambar Pada IklanDapatDilihatdenganJelas

\begin{tabular}{|l|c|c|c|}
\hline \multicolumn{1}{|c|}{ Pernyataan } & Frekuensi & Persentasi & \multirow{2}{*}{$\begin{array}{c}\text { Rata- } \\
\text { rata }\end{array}$} \\
\hline 4 = Sangat Setuju & 17 & $50 \%$ & \\
\cline { 1 - 3 } 3 = Setuju & 17 & $50 \%$ & \multirow{3}{*}{3.38} \\
\cline { 1 - 3 } 2 = Tidak Setuju & 0 & $0 \%$ & \\
\cline { 1 - 3 } 1 = Sangat Tidak Setuju & 0 & $0 \%$ & \\
\cline { 1 - 3 } Total & 34 & $100 \%$ & \\
\cline { 1 - 3 } & &
\end{tabular}

Berdasarkan tabel 4 mengenai gambar iklan dapat dilihat dengan jelas di atas, menunjukkan bahwa seluruh responden menjawab setuju dan sangat setuju bahwa gambar pada iklan televise mengenai Covid-19 dari Unilever Indonesia yang berjudul "K-U-N-C-I Menangkal Virus Corona" dapat dilihat dengan jelas oleh penontonnya. Sebanyak 17 responden (50\%) menjawab sangat setuju, 17 responden lainnya (50\%) menjawab setuju, dan tidak ada yang menjawab tidak setuju atau sangat tidak setuju. Berdasarkan data tersebut dapat ditarik kesimpulan bahwa seluruh responden sepakat bahwa gambar pada iklan televise mengenai Covid-19 dari Unilever Indonesia yang berjudul "K-U-N-C-I Menangkal Virus Corona" dapat dilihat dengan jelas. 
Tabel 5. Komposisi Warna Iklan

\begin{tabular}{|l|c|c|c|}
\hline \multicolumn{1}{|c|}{ Pernyataan } & Frekuensi & Persentasi & \multirow{2}{*}{$\begin{array}{c}\text { Rata- } \\
\text { rata }\end{array}$} \\
\cline { 1 - 3 } 4 = Sangat Setuju & 15 & $44,1 \%$ & \\
\cline { 1 - 3 } 3 = Setuju & 18 & $52,9 \%$ & \multirow{2}{*}{3.41} \\
\cline { 1 - 3 } 2 = Tidak Setuju & 1 & $2,9 \%$ & \\
\cline { 1 - 3 } 1 = Sangat Tidak Setuju & 0 & $0 \%$ & \\
\cline { 1 - 3 } Total & 34 & $100 \%$ & \\
\cline { 1 - 3 } & & &
\end{tabular}

Berdasarkan tabel 5 tentang komposisi warna iklan di atas, dapat diketahui bahwa paling banyak responden menjawab setuju bahwa komposisi warna pada iklan televise mengenai Covid-19 dari Unilever Indonesia yang berjudul "K-U-N-C-I Menangkal Virus Corona" cukup tajam dan serasi sehingga enak dilihat. Sebanyak 15 responden $(44,1 \%)$ menjawab sangat setuju, 18 responden $(52,9 \%)$ menjawab setuju, 1 responden $(2,9 \%)$ responden menjawab tidak setuju, dan tidak ada yang menjawab sangat tidak setuju. Berdasarkan data tersebut, dapat disimpulkan bahwa iklan televise mengenai Covid-19 dari Unilever Indonesia yang berjudul "K-U-N-C-I Menangkal Virus Corona" memiliki komposisi warna yang cukup tajam dan serasi sehingga enak dilihat.

Tabel 6. Pesan Iklan Mudah Diuraikan

\begin{tabular}{|l|c|c|c|}
\hline \multicolumn{1}{|c|}{ Pernyataan } & Frekuensi & Persentasi & \multirow{2}{*}{$\begin{array}{c}\text { Rata- } \\
\text { rata }\end{array}$} \\
\hline 4 = Sangat Setuju & 16 & $47,1 \%$ & \\
\cline { 1 - 3 } 3 = Setuju & 18 & $52,9 \%$ & \multirow{2}{*}{3.47} \\
\cline { 1 - 3 } 2 = Tidak Setuju & 0 & $0 \%$ & \\
\cline { 1 - 3 } 1 = Sangat Tidak Setuju & 0 & $0 \%$ & \\
\cline { 1 - 3 } Total & 34 & $100 \%$ & \\
\cline { 1 - 3 } & &
\end{tabular}

Berdasarkan table 6 tentang pesan iklan mudah diuraikan di atas, dapat diketahui bahwa paling banyak responden menjawab setuju bahwa pesan iklan televise mengenai Covid-19 dari Unilever Indonesia yang berjudul "K-U-N-C-I Menangkal Virus Corona” mudah diuraikan dengan jelas sesuai pengetahuan responden. Sebanyak 16 responden $(47,1 \%)$ menjawab sangat setuju, 18 responden $(52,9 \%)$ menjawab setuju, dan tidak ada yang menjawab tidak setuju atau sangat tidak setuju. Berdasarkan data tersebut, dapat disimpulkan bahwa pesan iklan televise mengenai Covid-19 dari Unilever Indonesia yang berjudul "K-U-N-C-I Menangkal Virus Corona" mudah diuraikan dengan jelas sesuai pengetahuan yang dimiliki oleh responden.

\section{Tabel 7. Pesan Iklan Mudah Digambarkan dalam Ingatan}




\begin{tabular}{|c|c|c|c|}
\hline Pernyataan & Frekuensi & Persentasi & $\begin{array}{l}\text { Rata- } \\
\text { rata }\end{array}$ \\
\hline 4 = Sangat Setuju & 13 & $38,2 \%$ & \multirow{5}{*}{3.38} \\
\hline $3=$ Setuju & 21 & $61,8 \%$ & \\
\hline $2=$ Tidak Setuju & 0 & $0 \%$ & \\
\hline 1 = Sangat Tidak Setuju & 0 & $0 \%$ & \\
\hline Total & 34 & $100 \%$ & \\
\hline
\end{tabular}

Berdasarkan tabel 7 tentang pesan iklan mudah digambarkan dalam ingatan di atas, dapat diketahui bahwa paling banyak responden menjawab setuju bahwa iklan televise mengenai Covid-19 dari Unilever Indonesia yang berjudul "K-U-N-C-I Menangkal Virus Corona" mudah digambarkan dengan jelas dalam ingatan responden. Sebanyak 13 responden $(38,2 \%)$ menjawab sangat setuju, 21 responden $(61,8 \%)$ menjawab setuju, dan sisanya tidak ada yang menjawab tidak setuju atau sangat tidak setuju. Berdasarkan data tersebut, dapat disimpulkan bahwa pesan iklan televise mengenai Covid-19 dari Unilever Indonesia yang berjudul "K-U-N-C-I Menangkal Virus Corona" mudah digambarkan dengan jelas dalam ingatan responden.

Tabel 8. Iklan Relevan untuk Memenuhi Kebutuhan

\begin{tabular}{|l|c|c|c|}
\hline \multicolumn{1}{|c|}{ Pernyataan } & Frekuensi & Persentasi & \multirow{2}{*}{$\begin{array}{c}\text { Rata- } \\
\text { rata }\end{array}$} \\
\hline 4 = Sangat Setuju & 10 & $29,4 \%$ & \\
\cline { 1 - 3 } 3 = Setuju & 23 & $67,6 \%$ & \multirow{2}{*}{3.26} \\
\cline { 1 - 3 } 2 = Tidak Setuju & 1 & $2,9 \%$ & \\
\cline { 1 - 3 } = Sangat Tidak Setuju & 0 & $0 \%$ & \\
\cline { 1 - 3 } Total & 34 & $100 \%$ & \\
\cline { 1 - 3 } & \multicolumn{2}{|c|}{} &
\end{tabular}

Berdasarkan tabel 8 tentang iklan relevan untuk memenuhi kebutuhan di atas, dapat diketahui bahwa paling banyak responden menjawab setuju bahwa iklan televise mengenai Covid-19 dari Unilever Indonesia yang berjudul "K-U-N-C-I Menangkal Virus Corona" relevan untuk memenuhi kebutuhan responden. Sebanyak 10 responden $(29,4 \%)$ menjawab sangat setuju, 23 responden $(67,6 \%)$ menjawab setuju, 1 orang $(2,9 \%)$ menjawab tidak setuju dan tidak ada yang menjawab sangat tidak setuju. Berdasarkan data tersebut dapat disimpulkan bahwa iklan televise mengenai Covid-19 dari Unilever Indonesia yang berjudul "K-U-N-C-I Menangkal Virus Corona" dirasa relevan dalam memenuhi kebutuhan responden. 
Tabel 9. Kata-kata dalam Iklan Mudah Dimengerti

\begin{tabular}{|c|c|c|c|}
\hline Pernyataan & Frekuensi & Persentasi & $\begin{array}{c}\text { Rata- } \\
\text { rata }\end{array}$ \\
\hline 4 = SangatSetuju & 10 & $29,4 \%$ & \multirow{5}{*}{3.26} \\
\hline $3=$ Setuju & 23 & $67,6 \%$ & \\
\hline 2 = TidakSetuju & 1 & $2,9 \%$ & \\
\hline 1 = SangatTidakSetuju & 0 & $0 \%$ & \\
\hline Total & 34 & $100 \%$ & \\
\hline
\end{tabular}

Berdasarkan tabel 9 tentang kata-kata dalam iklan mudah dimengerti di atas, dapat diketahui bahwa paling banyak responden menjawab setuju bahwa iklan televise iklan televise mengenai Covid-19 dari Unilever Indonesia yang berjudul "K-U-N-C-I Menangkal Virus Corona" menggunakan kata-kata yang mudah dimengerti. Sebanyak 10 responden $(29,4 \%)$ menjawab sangat setuju, 23 responden $(67,6 \%)$ menjawab setuju, 1 orang $(2,9 \%)$ menjawab tidak setuju dan tidak ada yang menjawab sangat tidak setuju. Berdasarkan data tersebut dapat disimpulkan bahwa kata-kata dalam iklan televise iklan televise mengenai Covid-19 dari Unilever Indonesia yang berjudul "K-U-N-C-I Menangkal Virus Corona" mudah dimengerti oleh penontonnya.

Tabel 10. Pesan Iklan Dipaparkan dengan Jelas

\begin{tabular}{|c|c|c|c|}
\hline Pernyataan & Frekuensi & Persentasi & $\begin{array}{c}\text { Rata- } \\
\text { rata }\end{array}$ \\
\hline $4=$ Sangat Setuju & 13 & $38,2 \%$ & \multirow{5}{*}{3.38} \\
\hline $3=$ Setuju & 21 & $61,8 \%$ & \\
\hline $2=$ Tidak Setuju & 0 & $0 \%$ & \\
\hline 1 = Sangat Tidak Setuju & 0 & $0 \%$ & \\
\hline Total & 34 & $100 \%$ & \\
\hline
\end{tabular}

Berdasarkan tabel 10 tentang pesan iklan dipaparkan dengan jelas di atas, dapat diketahui bahwa paling banyak responden menjawab setuju bahwa pesan iklan televise iklan televise mengenai Covid-19 dari Unilever Indonesia yang berjudul "K-U-N-C-I Menangkal Virus Corona" dipaparkan dengan jelas. Sebanyak 13 responden $(38,2 \%)$ menjawab sangat setuju, 21 responden $(61,8 \%)$ menjawab setuju, dan sisanya tidak ada yang menjawab tidak setuju atau sangat tidak setuju. Berdasarkan data tersebut dapat disimpulkan bahwa pesan iklan televise iklan televise mengenai Covid-19 dari Unilever Indonesia yang berjudul "K-U-N-C-I Menangkal Virus Corona” dipaparkan dengan jelas. 
Tabel 11. Kredibilitas Pengiklan

\begin{tabular}{|l|c|c|c|}
\hline \multicolumn{1}{|c|}{ Pernyataan } & Frekuensi & Persentasi & \multirow{2}{*}{$\begin{array}{c}\text { Rata- } \\
\text { rata }\end{array}$} \\
\cline { 1 - 3 } 4 = Sangat Setuju & 12 & $35,3 \%$ & \\
\cline { 1 - 3 } 3 = Setuju & 21 & $61,8 \%$ & \multirow{2}{*}{3.32} \\
\cline { 1 - 3 } 2 = Tidak Setuju & 1 & $2,9 \%$ & \\
\cline { 1 - 3 } 1 = Sangat Tidak Setuju & 0 & $0 \%$ & \\
\cline { 1 - 3 } Total & 34 & $100 \%$ & \\
\cline { 1 - 3 } & &
\end{tabular}

Berdasarkan tabel 11 tentang kredibilitas pengiklan di atas, dapat diketahui bahwa paling banyak responden menjawab setuju bahwa pengiklan dari iklan televise mengenai Covid-19 dari Unilever Indonesia yang berjudul "K-U-N-C-I Menangkal Virus Corona" memiliki kredibilitas yang tinggi. Sebanyak 12 responden $(35,3 \%)$ menjawab sangat setuju, 21 responden $(61,8 \%)$ menjawab setuju, dan tidak ada yang menjawab tidak setuju atau sangat tidak setuju. Berdasarkan data tersebut dapat ditarik kesimpulan bahwa pengiklan iklan televise mengenai Covid-19 dari Unilever Indonesia yang berjudul "K-UN-C-I Menangkal Virus Corona" memiliki kredibilitas yang tinggi. Pengiklan dari iklan tersebut adalah Unilever Indonesia.

Tabel 12. Responden Suka Menonton Iklan

\begin{tabular}{|l|c|c|c|}
\hline \multicolumn{1}{|c|}{ Pernyataan } & Frekuensi & Persentasi & \multirow{2}{*}{$\begin{array}{c}\text { Rata- } \\
\text { rata }\end{array}$} \\
\hline 4 = Sangat Setuju & 7 & $20,6 \%$ & \\
\cline { 1 - 3 } 3 = Setuju & 25 & $73,5 \%$ & \multirow{2}{*}{3.14} \\
\cline { 1 - 3 } 2 = Tidak Setuju & 2 & $5,9 \%$ & \\
\cline { 1 - 3 } 1 = Sangat Tidak Setuju & 0 & $0 \%$ & \\
\cline { 1 - 3 } & 34 & $100 \%$ & \\
\cline { 1 - 3 } Total & 34 & &
\end{tabular}

Berdasarkan tabel 12 tentang responden suka menonton iklan di atas, dapat diketahui bahwa paling banyak responden menjawab setuju bahwa mereka suka menonton iklan televise mengenai Covid-19 dari Unilever Indonesia yang berjudul "K-U-N-C-I Menangkal Virus Corona”. Sebanyak 7 responden (20,6\%) menjawab sangat setuju, 25 responden $(73,5 \%)$ menjawab setuju, 2 responden $(5,9 \%)$ menjawab tidak setuju, dan tidak ada yang menjawab sangat tidak setuju. Berdasarkan data tersebut dapat disimpulkan bahwa responden suka menonton iklan televise mengenai Covid-19 dari Unilever Indonesia yang berjudul "K-U-N-C-I Menangkal Virus Corona". 
Tabel 13. Iklan Membuat PenontonIngin Terus Melihat

\begin{tabular}{|l|c|c|c|}
\hline \multicolumn{1}{|c|}{ Pernyataan } & Frekuensi & Persentasi & \multirow{2}{*}{$\begin{array}{c}\text { Rata- } \\
\text { rata }\end{array}$} \\
\cline { 1 - 3 } 4 = SangatSetuju & 6 & $17,6 \%$ & \\
\cline { 1 - 3 } 3 = Setuju & 20 & $58,8 \%$ & \multirow{2}{*}{2.94} \\
\cline { 1 - 3 } 2 = Tidak Setuju & 8 & $23,5 \%$ & \\
\cline { 1 - 3 } 1 = Sangat Tidak Setuju & 0 & $0 \%$ & \\
\cline { 1 - 3 } Total & 34 & $100 \%$ & \\
\cline { 1 - 3 } & & &
\end{tabular}

Berdasarkan tabel 13 tentang iklan membuat penonton ingin terus melihat, dapat diketahui bahwa paling banyak responden setuju bahwa iklan televise mengenai Covid19 dari Unilever Indonesia yang berjudul "K-U-N-C-I Menangkal Virus Corona" membuat penontonnya ingin terus melihat penonton tersebut. Sebanyak 6 responden $(17,6 \%)$ menjawab sangat setuju, 20 responden $(58,8 \%)$ menjawab setuju, 8 responden $(23,5 \%)$ menjawab tidak setuju, dan tidak ada yang menjawab sangat tidak setuju. Dari data tersebut dapat disimpulkan bahwa iklan televise mengenai Covid-19 dari Unilever Indonesia yang berjudul "K-U-N-C-I Menangkal Virus Corona" membuat penonton ingin terus melihat iklan tersebut.

Tabel 14. Preferensi

\begin{tabular}{|l|c|c|c|}
\hline \multicolumn{1}{|c|}{ Pernyataan } & Frekuensi & Persentasi & \multirow{2}{*}{$\begin{array}{c}\text { Rata- } \\
\text { rata }\end{array}$} \\
\hline 4 = Sangat Setuju & 7 & $20,6 \%$ & \\
\cline { 1 - 3 } 3 = Setuju & 25 & $73,5 \%$ & \multirow{2}{*}{3.14} \\
\cline { 1 - 3 } 2 = Tidak Setuju & 2 & $5,9 \%$ & \\
\cline { 1 - 3 } 1 = Sangat Tidak Setuju & 0 & $0 \%$ & \\
\cline { 1 - 3 } Total & 34 & $100 \%$ & \\
\cline { 1 - 3 } & &
\end{tabular}

Berdasarkan tabel 14 tentang preferensi di atas, dapat diketahui bahwa paling banyak respoden menjawab setuju. Sebanyak 7 responden $(20,6 \%)$ menjawab sangat setuju, 25 responden $(73,5 \%)$ menjawab setuju, 2 responden $(5,9 \%)$ menjawab tidak setuju, dan tidak ada yang menjawab sangat tidak setuju. Dari data tersebut dapat disimpulkan bahwa iklan televise mengenai Covid-19 dari Unilever Indonesia yang berjudul "K-U-N-C-I Menangkal Virus Corona" dapat membangun preferensi mengenai mutu dan nilai dari Unilever Indonesia sebagai pengiklan, menjadi lebih baik dibanding competitor sejenis. 
Tabel 15. Pendirian

\begin{tabular}{|l|c|c|c|}
\hline \multicolumn{1}{|c|}{ Pernyataan } & Frekuensi & Persentasi & $\begin{array}{c}\text { Rata- } \\
\text { rata }\end{array}$ \\
\cline { 1 - 3 } 4 = SangatSetuju & 5 & $14,7 \%$ & \\
\cline { 1 - 3 } 3 = Setuju & 27 & $79,4 \%$ & \multirow{3}{*}{30.8} \\
\cline { 1 - 3 } 2 = Tidak Setuju & 2 & $5,9 \%$ & \\
\cline { 1 - 3 } 1 = Sangat Tidak Setuju & 0 & $0 \%$ & \\
\cline { 1 - 3 } Total & 34 & $100 \%$ & \\
\cline { 1 - 2 } & &
\end{tabular}

Berdasarkan tabel 15 tentang pendirian di atas, dapat diketahui bahwa paling banyak responden menjawab setuju. Sebanyak 5 responden $(14,7 \%)$ menjawab sangat tidak setuju, 27 responden $(79,4 \%)$ menjawab setuju, 2 responden $(5,9 \%)$ menjawab tidak setuju dan tidak ada yang menjawab sangat tidak setuju. Berdasarkan data tersebut dapat disimpulkan bahwa iklan televise mengenai Covid-19 dari Unilever Indonesia yang berjudul "K-U-N-C-I Menangkal Virus Corona" dapat meyakinan pendirian atau keyakinan responden terhadap Unilever Indonesia.

Tabel 16. Iklan Disukai atau Tidak

\begin{tabular}{|l|c|c|c|}
\hline \multicolumn{1}{|c|}{ Pernyataan } & Frekuensi & Persentasi & \multirow{2}{*}{ Rata-rata } \\
\hline 4 = SangatSetuju & 8 & $23,5 \%$ & \\
\cline { 1 - 3 } 3 = Setuju & 25 & $73,5 \%$ & \multirow{2}{*}{3.20} \\
\cline { 1 - 3 } 2 = TidakSetuju & 1 & $2,9 \%$ & \\
\cline { 1 - 3 } 1 = SangatTidakSetuju & 0 & $0 \%$ & \\
\cline { 1 - 3 } & 34 & $100 \%$ & \\
\cline { 1 - 3 } Total & 34 &
\end{tabular}

Berdasarkan tabel 16 tentang iklan disukai atau tidak di atas, dapat diketahui bahwa paling banyak responden menjawab menyukai iklan televise mengenai Covid-19 dari Unilever Indonesia yang berjudul "K-U-N-C-I Menangkal Virus Corona”. Sebanyak 8 responden $(23,5 \%)$ menjawab sangat setuju, 25 responden $(73,5 \%)$ menjawab setuju, dan 1 responden $(2,9 \%)$ menjawab tidak setuju, dan tidak ada yang menjawab sangat tidak setuju. Dari data tersebut dapat disimpulkan bahwa mayoritas responden menyukai iklan televise mengenai Covid-19 dari Unilever Indonesia yang berjudul "K-U-N-C-I Menangkal Virus Corona".

Tabel 17. Mean Per Dimensi

\begin{tabular}{|c|l|c|}
\hline No. & \multicolumn{1}{|c|}{ Dimensi } & Rata-rata \\
\hline 1. & Perhatian & 3.43 \\
\hline 2. & Pemahaman & 3.34 \\
\hline 3. & Respon kognitif & 3.38 \\
\hline 4. & Respon afektif & 3.07 \\
\hline
\end{tabular}




\begin{tabular}{|l|l|l|}
\hline 5. & Sikap & 3.20 \\
\hline
\end{tabular}

Berdasarkan tabel 17 tentang mean per dimensi di atas, dapat diketahui bahwa dimensi dengan nilai rata-rata tertinggi adalah dimensi perhatian dengan nilai rata-rata sebesar 3,43. Sedangkan dimensi dengan mean terendah adalah respon afektif dengan nilai rata-rata 3.07. Dimensi perhatian memiliki nilai mean tertinggi, berarti dimensi tersebut memiliki pengaruh paling besar terhadap efektivitas iklan televise mengenai Covid-19 dari Unilever Indonesia yang berjudul "K-U-N-C-I Menangkal Virus Corona". Sedangkan dimensi respon afektif dengan nilai mean terendah, memiiki pengaruh paling kecil terhadap efektivitas iklan televise mengenai Covid-19 dari Unilever Indonesia yang berjudul "K-U-N-C-I Menangkal Virus Corona". Jika dilihat pada mean seluruh indikator di atas, dapat diketahui bahwa dimensi perhatian, pemahaman, dan respon kognitif memiliki nilai mean di atas 3,25 yang berarti termasuk ke dalam kategori sangat efektif. Sedangkan dua indicator lainnya memiliki nilai mean di atas 2,5 namun masih di bawah 3,25 yang berarti termasuk ke dalam kategori efektif berdasarkan rentang skala penilaian sebagai berikut.

\begin{tabular}{|c|c|c|c|}
\hline Sangat tidak efektif & Tidak efektif & Efektif & Sangat tidak efektif \\
\hline
\end{tabular}

\section{E. KESIMPULAN}

Dilihat dari penjelasan mengenai hasil dan kesimpulan di atas, dapat diambil kesimpulan bahwa iklan televise mengenai Covid-19 dari Unilever Indonesia yang berjudul "K-U-N-C-I Menangkal Virus Corona" sudah efektif. Hal tersebut berdasarkan jawaban responden yang rata-rata setuju dan sangat setuju pada setiap pernyataan kuesioner. Hal tersebut dapat dilihat pada tabel 17 mengenai mean per dimensi bahwa seluruh dimensi memiliki nilai rata-rata di atas angka 2,5 yang berarti seluruh dimensi tersebut efektif. Nilai-nilai mean per dimensi tersebut yakni dimensi perhatian sebesar 3,43, dimensi pemahaman 3,34, dimensi respon kognitif 3,38, dimensi respon afektif 3,07, dan dimensi sikap sebesar 3,20. Dimensi perhatian memiliki pengaruh paling besar dan dimensi afektif memiliki pengaruh paling kecil dalam efektivitas iklan televise mengenai Covid-19 dari Unilever Indonesia yang berjudul "K-U-N-C-I Menangkal Virus Corona".Namun, dari hasil tersebut dapat disimpulkan bahwa iklan televise mengenai Covid-19 dari Unilever Indonesia yang berjudul "K-U-N-C-I Menangkal Virus Corona" 
sudah efektif.

Penempatan iklan di televisi pada masa kini ternyata masih efektif. Oleh karenanya, ada baiknya jika penggunaan televise sebagai media iklan terus dikembangkan guna sebagai media dalam penyampaian informasi kepada masyarakat. Selain itu juga sebagai media edukasi untuk masyarakat mengenai hal-hal baru, seperti virus Covid-19 ini. Hasil penelitian ini juga dimaksudkan untuk digunakan pada penelitian selanjutnya yang sejenis. 


\section{DAFTAR PUSTAKA}

Ardhi, B. M., \& Sastika, W. (2018). Epic Model Dan Direct Rating Method: Efektivitas Iklan Media Sosial Instagram Batagor Hanimun Di Kota Cimahi Tahun 2018. EProceeding of Applied Science, 4(3), 1-9.

Biagi, S. (2010). Media/Impact: An Introduction to Mass Media (9th ed.). Singapore.

Fajar, T. (2019, March 5). Studi Nielsen: Pemirsa Indonesia Habiskan 5 Jam Nonton TV, 3 Jam Berselancar di Internet. Retrieved April 29, 2020, from economy.okezone.com website: https://economy.okezone.com/read/2019/03/05/320/2025987/studi-nielsenpemirsa-indonesia-habiskan-5-jam-nonton-tv-3-jam-berselancar-di-internet

Gunawan, L. (2014). Efektivitas Iklan Televisi Suzuki Karimun Wagon R di Masyarakat Surabaya. Jurnal E-Komunikasi, 2(3).

Hastuti, S. (2013). Efektivitas Iklan Layanan Masyarakat Di Televisi. Jurnal Ilmu Komunikasi, 2(2), 67-71.

Liu, Y., Gayle, A. A., Wilder-Smith, A., \& Rocklöv, J. (2020). The reproductive number of COVID-19 is higher compared to SARS coronavirus. Journal of Travel Medicine, 27(2), 1-4. https://doi.org/https://doi.org/10.1093/jtm/taaa021

Octavianti, T. (2016). Efektivitas Iklan Televisi Bukalapak edisi "Gunakan Jarimu dan Jadilah Pahlawan di Bukalapak" pada Masyarakat Surabaya. Jurnal E-Komunikasi, $4(1)$.

Priyono. (2016). Metode Penelitian Kuantitatif. Sidoarjo: ZIFATAMA PUBLISHING.

Sekarwulan, A., Novita, Jamil, H. P., \& Safitri, D. (2020). Peran Instagram @ p2ptmkemenkesri Sebagai Media Kampanye Kesehatan. Communications, 2(1).

Shauma, A., \& A, Z. A. (2015). EFEKTIVITAS IKLAN POLITIK DI TELEVISI (Studi Deskriptif Kuantitatif Iklan Politik Aburizal Bakrie Versi Motivasi Anak Indonesia Pada Pemilih Pemula di Surabaya. Jurnal Ilmu Komunikasi, 7(2), 1-10.

Veerkumar, V., \& Jaiswal, N. (2015). Impact of Television Advertisement on Purchases made for children. Hamburg: Anchor Academic Publishing. 